\title{
Analysis on Some Physical and Chemical Properties of Oreke Dolomite Deposit
}

\author{
Jide Muili Akande ${ }^{1}$, Sunday Ayodele Agbalajobi ${ }^{2}$ \\ ${ }^{1}$ Department of Mining Engineering, Federal University of Technology, Akure, Nigeria \\ ${ }^{2}$ Department of Mineral Resources Engineering, Kwara State Polytechnic, Ilorin, Nigeria \\ Email: akandejn@yahoo.com, ayodele2kid@gmail.com
}

Received November 10, 2012; revised January 3, 2013; accepted January 31, 2013

\begin{abstract}
The suitability of Oreke dolomite in Kwara State, Nigeria as a raw material for the manufacturing of refractories was investigated. The Oreke dolomite samples were mingled with feldspar, clay, and quartz to form a blend. The fifteen (15) Blend samples were moulded and analyzed for their chemical, physical and mechanical properties. The characterization was carried out in accordance with American Society of Testing and Material (ASTM). The blend samples were tested for various refractory properties such as bulk density, porosity, cold crushing strength, linear shrinkage, refractoriness and others like water absorption and compressive strength. The chemical composition of the Blend was determined, using X-Ray Fluorescence Spectrometer and the result shows that Silica is $60 \%$, Alumina is $11.5 \%$, Iron Oxide is $0.48 \%$, Calcium Oxide is $10 \%$, Magnesium is $6.4 \%$, Alkali is $10.4 \%$, and Loss of Ignition of the sample is $15.28 \%$. The addition of $10 \%-12 \%$ quart contents with dolomite of $20 \%-25 \%$ contents complements the percentage of silica in the blend thereby improving the properties of the blend. The strength characterization shows that the Compressive Strength (mean value) of the blend samples is $5.65 \mathrm{~N} / \mathrm{m}^{2}$ with respect firing temperature. The strength classification varies between medium to high and was found to satisfy the allowable standard values for the production of refractory wares.
\end{abstract}

Keywords: Dolomite; Quartz; Feldspar; Clay; Deposit; Blend; Refractories; Composition

\section{Introduction}

Dolomite appears to form in many different types of environment and can have varying structural, textural and chemical characteristics. Some researchers have stated "there are dolomites and dolomites", meaning that there may not be one single mechanism by which dolomite can form [1].

Much modern dolomite differs significantly from the bulk of the dolomite found in the rock record, leading researchers to speculate that environments where dolomite formed in the geologic past differ significantly from those where it forms today [1].

Dolomite production in Nigeria was dated back to 1960, it was discovered in Lokoja (Kogi State) and Igbeti marble development in Oyo State followed. Also, dolomites deposits have been discovered in different areas among them are Alagutan dolomite field in Oyo State, Oreke in Ifelodun Local Government area of Kwara State and Ikepsi in Edo State [2].

Many limestones contain small amounts of dolomite and the term dolomite as a rock name is usually confined to rock with more than $15 \%$ magnesium carbonate. Dolomites may occur as evaporates. Calcite limestones are readily dolomitized, and in modern sediments dolo- mite seems to form as a result of penecontemporaneous [3].

Dolomite are of economic importance to man by virtue of its versatile physical, mineralogical and chemical properties that recommend them for numerous and building material. It also used for making refractory furnaces lining and as a source of carbon dioxide [4]; Many industries like paint, chemical, pharmaceutical and cosmetics utilize dolomite as major raw materials.

Many researchers have examined the relationship between physical and chemical properties of various carbonate rocks [5]. The attempts have not met with much success because of the homogenous nature of the rock.

Dolomite, $\mathrm{CaMg}\left(\mathrm{CO}_{3}\right)_{2}$ (calcium magnesium carbonate), dolomite rocks are present as sedimentary layers in many areas and as products of regional metamorphism of carbonate rocks. Dolomite is used as ornamental stone and raw materials to manufacture cement and magnesium oxide for refractories [6]. Limestone and dolomite constitute a group of raw materials commonly referred as carbonate rocks [7]. They represent the basic materials from which cement, lime, most building stones and a significant percentage of crushed stoned are produced.

Refractories materials are all the materials that are 
principally incorporated into the final refractory product. It also often comprises of auxiliary materials as binders, which affect the intermediate properties of the product [8]. The basic raw materials for refractories ware are dolomite, ball (plastic) clay, feldspar and quartz. Other additional materials include Kaloin, Calcite and Talc. Raw materials can either be natural (e.g. clays, feldspar, and quartz) or artificial (e.g. frits, oxides, pacifiers, and pigments) [8].

\section{Location of the Study Area}

The study area covered four selected villages within South-Western districts of Kwara, Kogi and Ekiti State where dolomite, clay, feldspar and quartz were collected. The villages are Oreke, Itobe, Obajana and Ijero Ekiti. Figure 1 and Table 1 showed the geological Map showing the study area and co-ordinates of the study area, respectively.

\section{Methodology}

\subsection{Determination of Chemical Composition}

The samples were tested in the laboratory to determine their chemical composition using X-Ray Fluorescence (XRF) spectrometer and Atomic Absorption Spectrophotometer (AAS).

\subsection{Determination of Linear Shrinkage of the Blends}

The linear firing shrinkage determined as FS using Equation (1) the test was carried out in accordance with ASTM
[9]. The maximum temperature of the kiln used for this study is $1000^{\circ} \mathrm{C}$.

$$
\text { Fired Shrinkage }(F S)=\frac{D L-F L}{D L} \times 100 \%
$$

where: $F S$ = Fired Shrinkage;

$D L=$ Dried Length, $\mathrm{m}$;

$F L=$ Fired Length, $\mathrm{m}$.

\subsection{Determination of Water Absorption of the Blends}

The test was carried out in accordance with ASTM [10]. The water absorption was calculated using Equation (2)

$$
\text { Water Absorption }(W A)=\frac{S-D}{D} \times 100 \%
$$

where: $W A=$ Water Absorption;

$S=$ Soaked Weight, g;

$D=$ Dry Weight, g.

Table 1. Location of study area/coordinates.

\begin{tabular}{ccccc}
\hline \multirow{2}{*}{$\begin{array}{c}\text { Sample } \\
\text { Location }\end{array}$} & $\begin{array}{c}\text { Sample } \\
\text { Type }\end{array}$ & L.G.A. & \multicolumn{2}{c}{ Coordinates of Location } \\
\cline { 4 - 5 } & & & Latitude & Longitude \\
\hline Oreke & Dolomite & Ifelodun & $08^{\circ} 29^{\prime} \mathrm{N}$ & $005^{\circ} 12^{\prime} \mathrm{E}$ \\
Itobe & Clay & Ofu & $07^{\circ} 25^{\prime} \mathrm{N}$ & $006^{\circ} 43^{\prime} \mathrm{E}$ \\
Obajana & Feldspar & Lokoja & $07^{\circ} 54^{\prime} \mathrm{N}$ & $006^{\circ} 25^{\prime} \mathrm{E}$ \\
Ijero & Quartz & Ijero & $07^{\circ} 49^{\prime} \mathrm{N}$ & $005^{\circ} 04^{\prime} \mathrm{E}$ \\
\hline
\end{tabular}

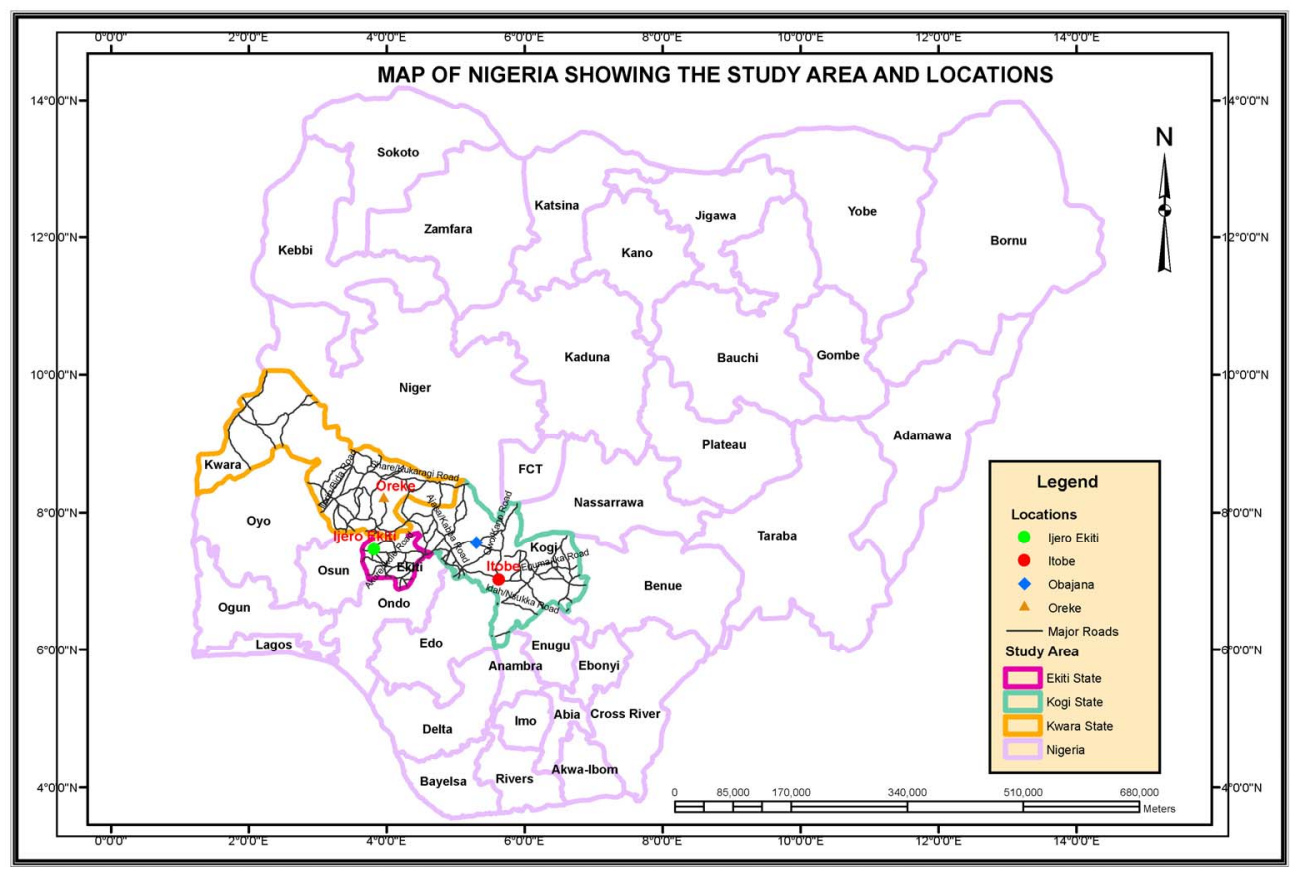

Figure 1. The geological map of Nigeria showing study area and locations. 


\subsection{Determination of Porosity of the Blends}

The test was carried out in accordance with ASTM [11]. The porosity was calculated using Equation (3) Proposed by Ekwere [12]

$$
\operatorname{Porosity}(P)=\frac{W-D}{W-S}
$$

where: $W=$ Soaked Weight, g;

$D=$ Dry Weight, g;

$S=$ Suspended weight, $\mathrm{g}$.

\subsection{Determination of Bulk Density of the Blends}

The test was carried out in accordance with ASTM [11]. The bulk density of blend samples was calculated using Equation (4) proposed by Ekwere [12]

$$
\text { Bulk density }=\frac{M d}{V}
$$

where: $M d=$ Dried mass (g)

$V=$ Volume $\left(\mathrm{cm}^{3}\right)$

\subsection{Determination of Cold Crushing Strength of the Blends}

The test was carried out in accordance with ASTM [13]. Cold Crushing Strength was then calculated using Equation (5)

$$
C C S=\frac{L}{A}
$$

Where: $L=$ Maximum load $(\mathrm{kN})$

$A=$ Cross-Sectional Area, $\mathrm{m}^{2}$

\subsection{Determination Compressive Strength of the Blends}

This was carried in accordance with method suggested by International Society of Rock Mechanic Commission (ISRM, [14]). The uniaxial compressive strength was determined using Equation (6)

$$
C o=\frac{P}{A}=\frac{S-D}{D} \times 100 \%
$$

where: $C o=$ Uniaxial compressive strength (MPa);

$P=$ The applied peak load $(\mathrm{kN})$;

$W=$ Width of the sample (m);

$D=$ Height of the sample (m).

\section{Results and Discussion}

\subsection{Results of the Analysis}

\subsubsection{Results of Sample Chemical Composition}

The results of the chemical composition analysis of selected dolomite, clay and feldspar samples are shown in

\section{Tables 2-4.}

4.1.2. Results of Linear Shrinkage of the Blends The results of the cylindrical blend sample tested for their compressive strength after firing are in Table 5.

\subsubsection{Results of the Water Absorption of the Bend}

The results of the cylindrical blend sample tested for their

Table 2. Chemical composition of oreke dolomite.

\begin{tabular}{cc}
\hline Parameters & Level of Detected (\%) \\
\hline $\mathrm{SiO}_{2}$ & - \\
$\mathrm{Al}_{2} \mathrm{O}_{3}$ & - \\
$\mathrm{Fe}_{2} \mathrm{O}_{3}$ & - \\
$\mathrm{CaO}$ & 29.48 \\
$\mathrm{MgO}$ & 18.97 \\
LOI & 44.45 \\
Others & - \\
\hline
\end{tabular}

Table 3. Chemical composition of obajana clay.

\begin{tabular}{cc}
\hline Parameters & Level of Detected (\%) \\
\hline $\mathrm{SiO}_{2}$ & 66.17 \\
$\mathrm{Al}_{2} \mathrm{O}_{3}$ & 13.77 \\
$\mathrm{Fe}_{2} \mathrm{O}_{3}$ & 0.69 \\
$\mathrm{CaO}$ & 0.36 \\
$\mathrm{MgO}$ & 0.11 \\
$\mathrm{~K}_{2} \mathrm{O}+\mathrm{Na}_{2} \mathrm{O}$ & 16.52 \\
$\mathrm{TiO}_{2}, \mathrm{P}_{2} \mathrm{O}_{5}, \mathrm{SO}_{3}$ etc & Trace \\
$\mathrm{LOI}_{\left(\mathrm{H}_{2} \mathrm{O}\right)}$ & 0.62 \\
\hline
\end{tabular}

Table 4. Chemical composition of itobe feldspar.

\begin{tabular}{cc}
\hline Parameter & Level of Detected (\%) \\
\hline $\mathrm{SiO}_{2}$ & 64.00 \\
$\mathrm{Al}_{2} \mathrm{O}_{3}$ & 15.31 \\
$\mathrm{Fe}_{2} \mathrm{O}_{3}$ & 0.76 \\
$\mathrm{CaO}$ & 0.31 \\
$\mathrm{MgO}$ & 0.12 \\
$\mathrm{~K}_{2} \mathrm{O}+\mathrm{Na}_{2} \mathrm{O}$ & 14.79 \\
$\mathrm{TiO}_{2}, \mathrm{P}_{2} \mathrm{O}_{5}, \mathrm{SO}_{3}$ etc. & Trace \\
$\mathrm{LOI}\left(\mathrm{H}_{2} \mathrm{O}\right)$ & 0.77 \\
\hline
\end{tabular}

Table 5. Linear shrinkage of the blends at varied temperature.

\begin{tabular}{ccccccc}
\hline Temp. $\left({ }^{\circ} \mathrm{C}\right)$ & $\mathrm{L}_{1}$ & $\mathrm{~L}_{2}$ & $\mathrm{~L}_{3}$ & $\mathrm{~L}_{4}$ & $\mathrm{~L}_{5}$ & $\mathrm{~L}_{\text {Ave. }}$ \\
\hline 850 & 1.66 & 2.00 & 1.66 & 1.00 & 2.00 & 1.67 \\
900 & 1.66 & 2.00 & 2.33 & 2.66 & 1.00 & 1.93 \\
1000 & 1.33 & 1.33 & 3.00 & 2.00 & 0.66 & 1.67 \\
\hline
\end{tabular}


water absorption after firing are in Table 6.

\subsubsection{Results of Porosity of the Blends}

The results of the cylindrical blend sample tested for their porosity after firing are in Table 7.

\subsubsection{Results of the Bulk Density of the Blends}

The results of the cylindrical blend sample tested for their bulk density after firing are in Table 8.

\subsubsection{Results of the Cold Crushing Strength}

The results of the cylindrical blend sample tested for their cold crushing strength after firing are in Table $\mathbf{9 .}$

\subsubsection{Results of compressive Strength of the Blends}

The results of the cylindrical blend sample tested for their compressive strength after firing are in Table $\mathbf{1 0 .}$

Table 6. Water absorption of the blends at varied temperatures.

\begin{tabular}{ccccccc}
\hline Temp. $\left({ }^{\circ} \mathrm{C}\right)$ & $\mathrm{W}_{1}$ & $\mathrm{~W}_{2}$ & $\mathrm{~W}_{3}$ & $\mathrm{~W}_{4}$ & $\mathrm{~W}_{5}$ & $\mathrm{~W}_{\text {Average }}$ \\
\hline 850 & 60 & 50 & 50 & 40 & 50 & 50 \\
900 & 60 & 40 & 40 & 60 & 40 & 48 \\
$1000^{\circ} \mathrm{C}$ & 20 & 20.2 & 20 & 20.1 & 20.2 & 21 \\
\hline
\end{tabular}

Table 7. Porosity of the blends at varied temperatures.

\begin{tabular}{ccccccc}
\hline Temp. $\left({ }^{\circ} \mathrm{C}\right)$ & $\mathrm{P}_{1}$ & $\mathrm{P}_{2}$ & $\mathrm{P}_{3}$ & $\mathrm{P}_{4}$ & $\mathrm{P}_{5}$ & $\mathrm{P}_{\text {Average }}$ \\
\hline 850 & 60 & 55.56 & 55.56 & 50 & 55.56 & 55.34 \\
900 & 75 & 66.67 & 50 & 60 & 50 & 60.33 \\
1000 & 25 & 25.1 & 25 & 25.2 & 25 & 25.06 \\
\hline
\end{tabular}

Table 8. Bulk density of the blends at varied temperatures.

\begin{tabular}{ccccccc}
\hline Temp. $\left({ }^{\circ} \mathrm{C}\right)$ & $\mathrm{B}_{1}$ & $\mathrm{~B}_{2}$ & $\mathrm{~B}_{3}$ & $\mathrm{~B}_{4}$ & $\mathrm{~B}_{5}$ & $\mathrm{~B}_{\text {Average }}$ \\
\hline 850 & 2.50 & 2.50 & 2.50 & 2.50 & 2.60 & 2.52 \\
900 & 1.25 & 1.25 & 1.67 & 1.67 & 1.67 & 1.50 \\
1000 & 1.67 & 1.67 & 1.67 & 1.67 & 1.68 & 1.67 \\
\hline
\end{tabular}

Table 9. Cold crushing strength of the blends at varied temperatures.

\begin{tabular}{cccc}
\hline Temp. $\left({ }^{\circ} \mathrm{C}\right) \mathrm{S} / \mathrm{N}$ & 850 & 900 & 1000 \\
\hline $\mathrm{C}_{1}$ & 25,410 & 22,840 & 26,600 \\
$\mathrm{C}_{2}$ & 25,470 & 22,870 & 24,130 \\
$\mathrm{C}_{3}$ & 24,790 & 22,940 & 24,860 \\
$\mathrm{C}_{4}$ & 24,860 & 22,290 & 25,550 \\
$\mathrm{C}_{5}$ & 25,610 & 21,900 & 25,710 \\
$\mathrm{C}_{\text {Ave. }}$ & 25,228 & 22,568 & 25,370 \\
\hline
\end{tabular}

\section{Discussion}

\subsection{Mixture of Dolomite, Clay, Feldspar, and Quartz to Form a Blend}

In Table 11, the average mass of the blends were the same all through the 15 blend samples characterised by varied temperatures. The percentage of clay and quartz was increased so as to have appreciable quantity of silica to improve the bond properties.

\subsection{Refractoriness Characterization of the Blend}

The refractoriness for the blend were $850^{\circ} \mathrm{C}, 900^{\circ} \mathrm{C}$ and $1000^{\circ} \mathrm{C}$ respectively, the values were lower than the normal values of $1580^{\circ} \mathrm{C}-1750^{\circ} \mathrm{C}$ according to Grimshaw [15]. This was as a result of the high silica content in the blend. The implication of this is that its use is restricted to non-ferrous material processing.

\subsection{Linear Relationship between Physical, Mechanical and Fired Properties of the Blends}

Figure 2 Shows the relationship between Cold Crushing Strength and appreciable dolomite contents in the Blends. Cold Crushing Strength at temperature of $850^{\circ} \mathrm{C}-1000^{\circ} \mathrm{C}$,

Table 10. Compressive strength of the blend at varied temperatures.

\begin{tabular}{cccc}
\hline Temp. $\left({ }^{\circ} \mathrm{C}\right) \mathrm{S} / \mathrm{N}$ & 850 & 900 & 1000 \\
\hline $\mathrm{A}_{1}$ & 0.7374 & 4.7888 & 10.561 \\
$\mathrm{~A}_{2}$ & 1.5334 & 4.2215 & 13.519 \\
$\mathrm{~A}_{3}$ & 1.3403 & 5.8300 & 3.0054 \\
$\mathrm{~A}_{4}$ & 1.2814 & 6.2304 & 10.316 \\
$\mathrm{~A}_{5}$ & 1.1101 & 6.0592 & 12.870 \\
$\mathrm{~A}_{\text {Ave. }}$ & 1.2005 & 5.4259 & 10.054 \\
\hline
\end{tabular}

Table 11. Samples mixture (dolomite, clay, feldspar and quartz).

\begin{tabular}{cccccccc}
\hline & \multicolumn{5}{c}{ Composition } \\
\cline { 2 - 7 } $\begin{array}{c}\text { Mineral } \\
\text { Sample }\end{array}$ & \multicolumn{2}{c}{$1000^{\circ} \mathrm{C}$} & \multicolumn{2}{c}{$900^{\circ} \mathrm{C}$} & \multicolumn{2}{c}{$850^{\circ} \mathrm{C}$} \\
\cline { 2 - 8 } & \multicolumn{2}{c}{$\mathrm{A}$} & \multicolumn{2}{c}{$\mathrm{B}$} & \multicolumn{2}{c}{$\mathrm{C}$} \\
\cline { 2 - 8 } & $(\mathrm{g})$ & $(\%)$ & $(\mathrm{g})$ & $(\%)$ & $(\mathrm{g})$ & $(\%)$ \\
\hline Dolomite & 625 & 25 & 550 & 22 & 500 & 20 \\
Quartz & 250 & 10 & 275 & 11 & 300 & 12 \\
Feldspar & 250 & 10 & 300 & 12 & 325 & 13 \\
Clay & 1275 & 55 & 1275 & 55 & 1275 & 55 \\
Average & 2400 & 100 & 2400 & 100 & 2400 & 100 \\
\hline
\end{tabular}


it can be seen that the cold crushing strength increases with the increase of dolomite $(20 \%-25 \%)$ and quartz $(10 \%-12 \%)$ content in the Blends.

Figure 3 Shows the relations between Bulk Density and appreciable dolomite contents in the Blends. The Blend was fired at temperature of $850^{\circ} \mathrm{C}-1000^{\circ} \mathrm{C}$, it can be seen that the bulk density increases (at $900^{\circ} \mathrm{C}$ ) and constant $\left(850^{\circ} \mathrm{C}\right.$ and $\left.1000^{\circ} \mathrm{C}\right)$ with relative increase of dolomite $(20 \%$ - 25\%) and quartz $(10 \%$ - 12\%) in the Blends. This expected since higher dolomite contents decrease the porosity.

Figure 4 Shows the relationship between porosity and appreciable dolomite contents in the Blends. The porosity at temperature of $850^{\circ} \mathrm{C}-1000^{\circ} \mathrm{C}$, it can be seen that the porosity decreases with increase of dolomite (20\% - 25\%) and quartz (10\% - 12\%) content in the Blends.

Figure 5 Shows the relationship between linear shrinkage and appreciable dolomite and quartz contents in the Blends. The linear shrinkage at temperature of $850^{\circ} \mathrm{C}$, it can be seen that the linear shrinkage relatively increases from blend sample number 1 to 2, then decreases at blend sample number 3 to 4 followed by sharp increases at blend sample number 5 , the variation falls within a narrow range. This is due to variation in chemical composition, particle size, and porosity. Also, the linear shrinkage

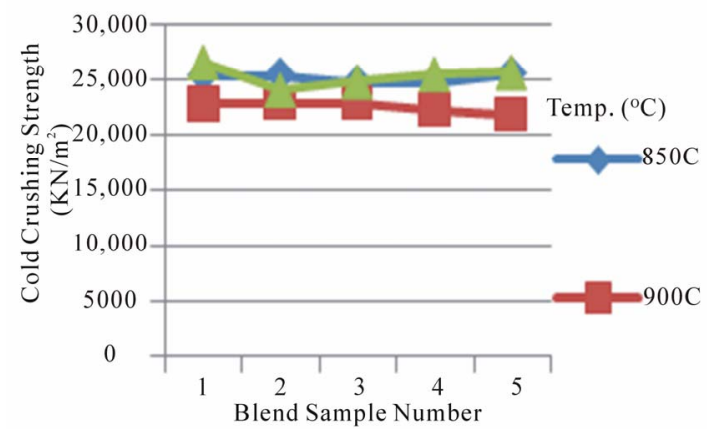

Figure 2. Linear relationship between cold crushing strength of $20 \%-25 \%$ dolomite and $10 \%-12 \%$ quartz contents in the blend at varied firing temperature.

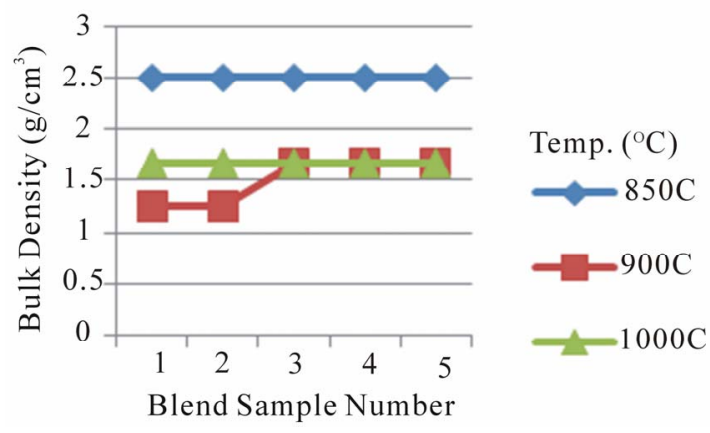

Figure 3. Linear relationship between bulk density of $\mathbf{2 0 \%}$ $25 \%$ dolomite and $10 \%-12 \%$ quartz contents in the blends at varied firing temperature. for blend sample number 1 to 5 relatively increases steadily then relatively decreases at the temperature $900^{\circ} \mathrm{C}$ and $1000^{\circ} \mathrm{C}$ of dolomite (20\% - 25\%) and quartz (10\% - 12\%) content in the Blends. The linear shrinkage shows that the blend samples are stable and could be processed for use as low refractory furnace linings.

\subsection{Chemical Composition of the Blend}

Figure 6 shows the chemical composition of the Blend.

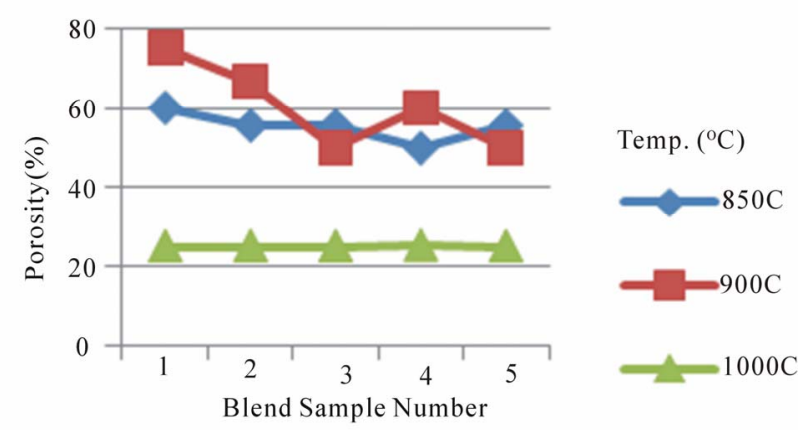

Figure 4. Linear relationship between porosity of $20 \%$ $25 \%$ dolomite and $10 \%-12 \%$ quartz contents in the blends at varied firing temperature.

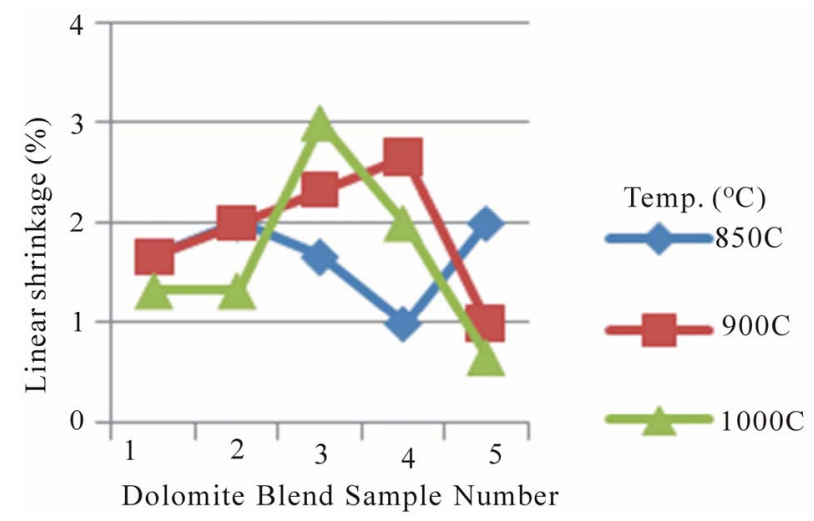

Figure 5. Linear relationship between linear shrinkage of $20 \%-25 \%$ dolomite and $10 \%-12 \%$ quartz contents in the blends at varied firing temperature.

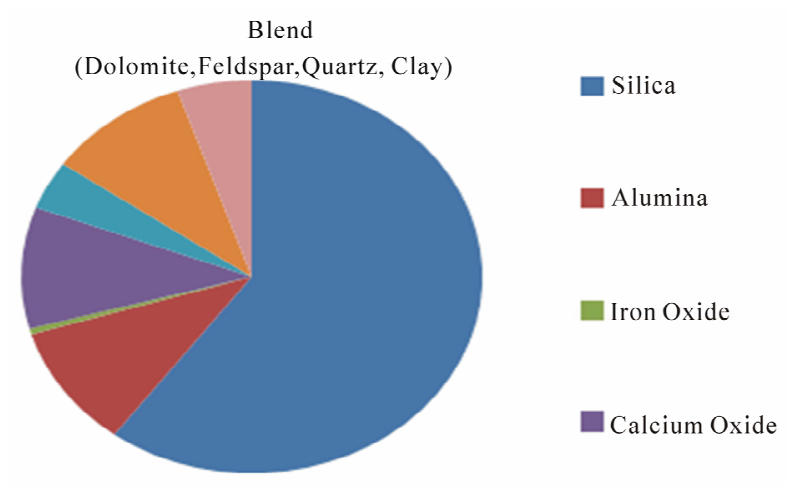

Figure 6. Chemical composition of the blend. 
Silica is $60 \%$, Alumina is $11.5 \%$, Iron Oxide is $0.48 \%$, Calcium Oxide is $10 \%$, Magnesium is $6.4 \%$, Alkali is $10.4 \%$, LOI is $15.28 \%$, and other trace oxides.

\section{Conclusions}

The results of the investigation were very useful and serve as a database for prospective investors and managers of metallurgical industries.

The tests on physical properties and chemical composition were carried out on all the fifteen (15) samples of the blend in accordance with American Society of Testing and Material (ASTM).

The addition of $10 \%-12 \%$ quart contents with dolomite of $20 \%-25 \%$ contents complements the percentage of silica in the blend thereby improving the properties of the blend. The strength characterization of the selected samples show that the Compressive Strength (mean value) of the blend sample vary from $1.2 \mathrm{~N} / \mathrm{m}^{2}-10.1 \mathrm{~N} / \mathrm{m}^{2}$ with respect firing temperature. The result indicates a strength classification medium to high.

The results of various analyses on Physical and Mechanical properties, and Chemical Composition of selected samples of Oreke Dolomite Deposit in the blend (dolomite, quartz, feldspar, and clay) was found to satisfy the allowable standard values for the production of refractory wares.

\section{REFERENCES}

[1] W. A. Deer, R. A. Howie and J. Zussman, “An Introduction to the Rock-Forming Minerals," 2nd Edition, Prentice Hall Longman, Upper Saddle River, 1996, pp. 489493.

[2] J. G. Adetoro, "History and Ownership Structure of Nigerian Marble Mining Company (NMMC) Ltd., Igbeti," Oyo State, 1986, pp. 1-8.

[3] D. G. A. Whitten and J. R. V. Brooks, "The Penguin Dic- tionary of Geology,” Penguin Press, New York, 1972, p. 131.

[4] H. H. Read, "Rutley Element of Mineralogy," 26th Edition, T. Murby and Co., Publishers, London, 1979, p. 279.

[5] J. E. Kogec, N. C. Trivedi, J. M. Barker and S. T. Krukowski, "Industrial Mineral and Rocks: Commodities Markets and Uses,” Society for Mining, Metallurgy and Exploration (SME), 2006, pp. 587

[6] C. A. Sorrel and G. F. Sandstrom, "The Rocks and Mineral of the World,” William Collins Sons and Co., Ltd., London, 1977, pp. 230.

[7] R. M. Goktan, “Discussion on ISRM Suggested Method for Determining the Shore Hardness Value for Rock," International Journal of Rock Mechanics and Mining Science, Vol. 43, No. 6, 2006, pp. 996-997.

[8] S. Alsop, "Key Properties of Ceramic Raw Materials," Journal of the Australasian Ceramics Society, Vol. 34, 1998, pp. 122-127.

[9] ASTM, "Standard Test Method for Drying and Fired Shrinkages of Ceramic Whiteware Clay,” 2010.

[10] ASTM, "Standard Test Methods for Size, Dimensional Measurements, and Bulk Density of Refractory Brick and Insulating Firebrick,” 2010.

[11] ASTM, "Standard Test Method for Apparent Porosity, Water Absorption, Apparent Specific Gravity, and Bulk Density of Burned Refractory Brick and shapes by Boiling Water,” 2010, pp. 6-8.

[12] I. I. Ekwere, "Characterization of Some Nigeria Clays for Ceramic Application," Proceedings of 1st National Conference of Faculty of Technology, Obafemi Awolowo University, Ile-Ife, 17-19 November 2009, pp. 32-37.

[13] ASTM, "Standard Test Methods for Cold Crushing Strength and Modulus of Rapture of Refractories," 2008.

[14] ISRM, "Experimental Calibration of Stress Intensity Factors of the International Society of Rock Mechanics Commission (ISRM) Standard,” 1989, pp. 13-23.

[15] R. W. Grimshaw, "The Chemistry and Physics of Clays," 4th Edition, Ernest Benn Publishers, London, 1971. 